\title{
HAK ASASI MANUSIA DALAM PERSPEKTIF NEGARA HUKUM BERDASARKAN PANCASILA
}

\author{
Otong Syuhada ${ }^{1}$
}

\begin{abstract}
ABSTRAK
Negara yang berdasarkan atas hukum merupakan negara yang menjunjung tinggi supremasi hukum. Hukum ditempatkan sebagai acuan atau patokan tertinggi dalam penyelenggaraan negara dan pemerintahannya, yang sesuai dengan ajaran kedaulatan hukum yang menempatkan hukum sebagai sumber kedaulatan, namun supremasi hukum dan hak asasi manusia (HAM) tampaknya masih menjadi pekerjaan rumah terberat yang harus diselesaikan Indonesia sejak republik ini berdiri pada 17 Agustus 1945

Metode penelitian yang digunakan adalah metode penelitian hukum normatif atau yang dikenal dengan istilah "legal research", karena yang dilakukan adalah meneliti bahan hukum pustaka atau data sekunder untuk mengetahui dan mengkaji perihal Hak Asasi Manusia Dalam Negara Hukum Pancasila. Sedangkan bahan hukum yang digunakan yaitu bahan hukum primer, bahan hukum sekunder dan bahan hukum tersier. Analisis data yang digunakan adalah analisis secara kualitatif.

Berdasarkan hasil analisis data, disimpulkan bahwa Negara hukum Indonesia adalah negara hukum Pancasila yang mempunyai karakteristik khusus yaitu Negara Indonesia merupakan suatu negara kekeluargaan, menjunjung tinggi asas kepastian dan keadilan, religious nation state, adanya kolaborasi hukum sebagai sarana perubahan masyarakat dan hukum, basis pembuatan dan pembentukan hukum nasional didasarkan pada prinsip hukum yang bersifat netral dan universal. Negara hukum Pancasila dapat menjadi negara hukum yang membahagiakan rakyatnya, karena mempunyai kemampuan untuk memilih yang terbaik bagi rakyatnya dan norma hukum yang dikristalkan menjadi undang-undang harus memiliki tujuan hukum untuk membahagiakan rakyatnya, sehingga mampu menghadirkan produk hukum yang mengandung nilai keadilan sosial (social justice).
\end{abstract}

\section{Kata Kunci : HAM, Negara Hukum, Pancasila}

\footnotetext{
${ }^{1}$ Dosen FH Universitas Majalengka, Email otsyu130270@gmail.com
} 
PRESUMPTION of LAW

Fakultas Hukum Universitas Majalengka

\section{A. Latar Belakang}

Sejak abad ke XVIII istilah negara hukum sudah lama dikenal dan dianut di banyak negara, istilah ini kemudian baru populer kira-kira abad XIX sampai dengan abad XX. Di Indonesia istilah negara hukum sudah dipergunakan sejak negara ini memproklamirkan diri sebagai negara yang merdeka dan berdaulat ${ }^{2}$.

Negara yang berdasarkan atas hukum merupakan negara yang menjunjung tinggi supremasi hukum. Hukum ditempatkan sebagai acuan atau patokan tertinggi dalam penyelenggaraan negara dan pemerintahannya, yang sesuai dengan ajaran kedaulatan hukum yang menempatkan hukum sebagai sumber kedaulatan. Hal tersebut menimbulkan munculnya istilah pemerintah di bawah hukum (government under the law). ${ }^{3}$ Adapun beberapa istilah yang dikenal untuk menyebut negara hukum antara lain Rechtstaat (Belanda), Rule of Law (Inggris), Etat de Droit (Prancis), dan Stato di Doritto (Italia). ${ }^{4}$

Penegasan Negara Kesatuan Republik Indonesia sebagai negara hukum telah dinormativisasi pada Pasal 1 ayat (3) Undang-Undang Dasar Negara Republik Indonesia Tahun 1945 yang menyatakan bahwa Negara Indonesia adalah negara hukum. Jauh sebelum itu, sebelum Undang-Undang Dasar Negara Republik Indonesia Tahun 1945 diamandemen, bentuk dari negara hukum Indonesia telah dibakukan dalam penjelasan UUD NRI 1945 dengan rumusannya yaitu "Negara Indonesia adalah negara hukum (rechtsstaat)." Dengan rumusan tersebut, mekanisme kehidupan berbangsa dan bernegara diatur oleh hukum (tertulis dan tidak tertulis). ${ }^{5}$

Konsep negara hukum lahir sebagai hasil perjuangan individu untuk melepaskan dirinya dari keterikatan serta tindakan sewenang-wenang penguasa. Atas dasar ini maka penguasa tidak dibenarkan melakukan tindakan sewenang-wenang kepada individu dan kekuasaannya harus pula dibatasi. Pembatasan kekuasaan dapat dilakukan melalui undang-undang atau peraturan perundang-undangan dan menurut Rukmana Amanwinata disebut dengan asas legalitas negara hukum. ${ }^{6}$

Istilah negara hukum di Indonesia sering disebut dengan rechtstaats atau the rule of law. Paham rechtstaats pada dasarnya bertumpu pada sistem hukum Eropa Kontinental dan walaupun dalam UUD 1945 istilah negara hukum disebut rechtstaats, tetapi secara normatif harus dibedakan dengan paham negara hukum dalam sistem hukum Eropa Kontinental ataupun konsep the rule hlm 11

${ }^{2}$ Nany Suryawati, Hak Asasi Politik Perempuan, Ideas Publishing, Gorontalo, 2020,

3 Munir Fuady, 2009, Teori Negara Hukum Modern (Rechtstaat), Refika Aditama, Bandung, hlm. 2.

${ }^{4}$ I Ketut Cahyadi Putra, Relevansi Konsep Negara Hukum Pancasila Dengan Welfare State Dalam Implementasinya Dengan Pelayanan Publik Di Indonesia, Jurnal, Magister Hukum Udayana, Vol. 6, No. 1, 2017, hlm https://ojs.unud.ac.id/index.php/jmhu/article/view/30607, diakses pada tanggal 09/09/2021. Pukul 21.05 WIB

${ }^{5}$ Ibid

6 Rukmana Amanwinata, "Pengaturan dan Batas Implementasi Kemerdekaan Berserikat dan Berkumpul dalam Pasal 28 UUD 1945", Disertasi, Program Pascasarjana Universitas Padjadjaran, Bandung, 1996, hlm. 122-123 
PRESUMPTION of LAW

Fakultas Hukum Universitas Majalengka

Volume 3 Nomor 2 Oktober 2021

of law dalam sistem hukum Anglo Saxon. Konsep negara hukum (rechtstaats) di Indonesia harus sesuai dengan nilai-nilai yang tercermin dalam Pancasila. Pemahaman utuh terhadap konsep Negara Hukum yang berdasarkan Pancasila dapat dilihat dari proses dan latar belakang lahirnya rumusan Pembukaan UUD 1945 yang merupakan pernyataan kehendak lahirnya negara Indonesia, serta sebagai dasar filosofis dan tujuan negara. Dari kajian dan pemahaman demikian, akan sampai pada suatu kesimpulan bahwa dalam konsep Negara Hukum yang berdasarkan Pancasila selain memiliki kesamaan, tetapi juga memiliki perbedaan dengan konsep negara hukum yang dikembangkan di negara lain. ${ }^{7}$

Apabila dibandingkan dengan model-model negara hukum rechsstaat dan rule of law maka Indonesia tidak dapat begitu saja dikategorikan sebagai salah satu dari keduanya. Prinsip-prinsip umum sebagai negara hukum telah dipenuhi oleh Indonesia, seperti: pengakuan terhadap hak asasi manusia, pembagian kekuasaan (triaspolitika) dan pemerintahan yang berdasarkan hukum. Juga terdapat kesamaan baik dengan negara hukum rechsstaat maupun rule of law. Dengan rechsstaat sama-sama mengharuskan keberadaan peradilan administrasi. Dengan rule of law sama-sama mengakui prinsip persamaan di depan hukum. Akan tetapi, sebagai negara hukum, Indoneisa memiliki karakteristik tersendiri. Pada intinya karakteristik tersebut adalah bahwa dalam pelaksanaan negara hukum Indonesia harus senantiasa mengacu pada nilai-nllai yang terdapat dalam Pancasila.

Terbentuknya suatu negara, berikut dengan penyelenggaraan kekuasaannya, tidak boleh mengurangi arti atau makna dari kebebasan hak-hak asasi kemanusiaan, oleh karena itu, adanya perlindungan dan penghormatan terhadap hak-hak asasi manusia merupakan pilar yang sangat penting dalam setiap Negara yang disebut sebagai Negara Hukum. Jika dalam suatu Negara, hak asasi manusia terabaikan atau dilanggar dengan sengaja dan penderitaan yang ditimbulkannya tidak dapat diatasi secara adil, maka Negara yang bersangkutan tidak dapat disebut sebagai Negara Hukum dalam arti yang sesungguhnya. Begitu pula Oemar Senoadji, yang menyatakan dalam Pemikirannya serta bisa dilihat dalam makalahnya yang berjudul: "Indonesia Negara Hukum". Ia menekankan perpaduan antara Indonesia dan unsur-unsur negara hukum. Ia berpandangan bahwa Negara Hukum Indonesia memiliki ciri-ciri khas Indonesia.

Pancasila merupakan sumber pokok hukum di Indonesia, sehingga Negara Hukum Indonesia dapat pula dinamakan sebagai Negara Hukum Pancasila yang salah satu cirinya adanya Hak asasi menjadi salah satu unsur terpenting negara hukum sesuai penghormatan harkat dan martabat manusia (human dinity) ditekankan pada keseimbangan perlindungan kepentingan individu dan masyarakat. Inti ciri khas hukum Indonesia tercermin dalam Hukum Adat sebagaimana dikemukakan oleh Soepomo, bahwa "struktur

7 Otong Syuhada, Karakteristik Negara Hukum Pancasila Yang Membahagiakan Rakyatnya, Journal Presumption of Law, Volume 3 Nomor 1 April 2021 hlm 3 https:// ejournal. unma.ac.id/ index.php/jpl/article/view/979 diakses pada tanggal 09/09/2021. Pukul $21.05 \mathrm{WIB}$ 
hukum adat" memandang bahwa kepentingan individual selaras dengan kepentingan $\operatorname{sosial}^{8}$. Namun supremasi hukum dan hak asasi manusia (HAM) tampaknya masih menjadi pekerjaan rumah terberat yang harus diselesaikan Indonesia sejak republik ini berdiri pada 17 Agustus 1945. Menilik tahun kebelakang saja, terdapat sejumlah catatan hitam dalam ranah hukum dan HAM. Diantaranya ruang untuk kebebasan berekspresi dan berpendapat di Indonesia semakin menyusut sepanjang 2020, antara lain karena terus adanya penerapan sewenang-wenang pasal-pasal karet dalam Undang-Undang Informasi dan Transaksi Elektronik (UU ITE). Momen pandemi menjadi titik di mana para penegak hukum memperlihatkan upaya eksesif untuk membungkam kebebasan berekspresi, baik dengan UU ITE atau regulasiregulasi lain yang menyusul ${ }^{9}$.

Melihat masih banyaknya bentuk pelanggaran HAM yang terjadi di Indonesia, maka peneliti ingin melakukan penelitian lebih lanjut yang akan dituangkan dalam bentuk karya ilmiah dengan judul "HAK ASASI MANUSIA DALAM PERSPEKTIF NEGARA HUKUM BERDASARKAN PANCASILA"

\section{B. Identifikasi Masalah}

Berdasarkan latar belakang sebagaimana yang telah diuraikan pada bagian sebelumnya, maka permasalahan yang dibahas dalam penulisan ini adalah

1. Bagaimana Hak Asasi Manusia Dalam Perspektif Negara Hukum Pancasila?

2. Bagaimana Konsep Negara Hukum Pancasila terhadap Hak Asasi Manusia dimasa yang akan datang?

\section{Tujuan Penelitian}

Berdasarkan Identifikasi Masalah di atas, maka tujuan yang akan dicapai dalam penelitian ini adalah sebagai berikut :

1. Untuk mengetahui dan menganalisis Hak Asasi Manusia Dalam Perspektif Negara Hukum Pancasila

2. Untuk mengetahui dan menganalisis Konsepsi Negara Hukum Pancasila terhadap Hak Asasi Manusia dimasa yang akan datang

\section{Metode Penelitian}

Jenis penelitian yang digunakan penulis adalah penelitian hukum normatif atau yang dikenal dengan istilah "legal research". ${ }^{10}$ Penelitian ini menggunakan pendekatan yuridis normatif yang artinya menemukankebenaran koherensi, yaitu adakah aturan hukum sesuai norma hukum dan

${ }^{8}$ I Ketut Cahyadi Putra, Relevansi Konsep Negara Hukum Pancasila .... Op.Cit hlm 4

9 Ayomi Amindoni, Covid-19 Memperburuk Situasi Ham Di Indonesia Pada 2020, Dengan Korban Lebih 150 Orang, 'UU ITE Masih Menjadi Momok', https:// www.bbc. com/indonesia/indonesia-56664120, diakses diakses pada tanggal 09/09/2021. Pukul 21.05 wib

${ }^{10}$ Peter Mahmud Marzuki, Penelitian Hukum, EdisiRevisi, Kencana, Jakarta, 2013, hlm. 47 
adakah norma yang berupa perintah atau larangan itu sesuai dengan prinsip hukum serta apakah tindakan (act) seseorang sesuai dengan norma hukum (bukan hanya sesuai dengan aturan hukum) atau prinsip hukum. Dalam penelitian hukum normatif sumber datanya adalah data sekunder. Yang diperoleh peneliti dari berbagai kepustakaan. Maka dalam metode pengumpulan data yang digunakan adalah studi kepustakaan. Studi kepustakaan adalah teknik pengumpukan data dengan mengadakan studi penelaahan terhadap buku, literatur-literatur, catatan dan laporan mengenai kasus yang terjadi berdasarkan permasalahan di atas. Bahan pustaka dapat berupa bahan primer atau bahan sekunder, dimana kedua bahan tersebut mempunyai karakteristik dan jenis yang berlainan. ${ }^{11}$

Analisis data yang digunakan adalah analisis secara kualitatif. Bentuk penelitian kualitatif memusatkan perhatian pada prinsip-prinsip umum yang mendasari perwujudan satuan-satuan gejala yang ada dalam kehidupan manusia atau pola-pola yang berlaku. ${ }^{12}$

\section{E. Hasil Penelitian dan Pembahasan}

\section{Hak Asasi Manusia Dalam Perspektif Negara Hukum Pancasila}

Hak asasi manusia sebagai anugerah dari Tuhan Yang Maha Esa melekat pada diri manusia, bersifat universal, kodrati, dan abadi, yang berkaitan dengan harkat dan martabat manusia. Setiap manusia diakui dan dihormati dengan hak asasi manusia tanpa membedakan warna kulit, jenis kelamin, kebangsaan, agama, usia, pandangan politik, status sosial, dan bahasa daerah. Bangsa Indonesia menyadari bahwa hak asasi manusia bersifat historis dan dinamis yang mana pelaksanaannya berkembang dalam kehidupan berbangsa, bernegara, dan bermasyarakat. Pentingnya hak asasi manusia bagi seluruh rakyat Indonesia tentunya memerlukan perlindungan hukum, perlindungan hukum tentang hak asasi manusia ini diatur dalam Undang-Undang Nomor 39 Tahun 1999 tentang hak asasi manusia. Penegakanan hak asasi manusia tentunya merupakan cerminan atau perwujudan dari sila pancasila yang kedua yaitu kemanusiaan yang adil dan beradap. Penegakan dari hak asasi manusia ini bukan hanya dilakukan oleh

para pejabat negara namun juga harus dilakukan dan dilaksanakan oleh semua rakyat Indonesia ${ }^{13}$. Hak asasi manusia (HAM) haruslah menjadi pilar utama penyelenggaraan negara, disamping adanya pembagian kekuasaan

${ }^{11}$ Bambang Waluyo, Penelitian Hukum dan Praktek, Cetakan Ketiga, Sinar Grafika, Jakarta, 2002, hlm 50

${ }^{12}$ Burhan Ashshofa, Metode Penelitian Hukum, PT . Rhineka Cipta, Jakarta, 1996, hlm. 21

${ }^{13}$ Lilis Eka Lestari, Penegakan Dan Perlindungan Hak Asasi Manusia Di Indonesia Dalam Konteks Implementasi Sila Kemanusiaan Yang Adil Dan Beradab, Jurnal Komunilasi Hukum, Vol. 5 No. 2, Agustus 2019, hlm 15. https://ejournal.undiksha.ac.id/ index.php/ jkh/article/view/16497, diakses pada tanggal 10/09/2021. Pukul 09.21 WIB 
dalam mekanisme checks and balances dengan dijaminnya independensi yudisial $^{14}$

Indonesia sebagai negara hukum yang termuat dalam Pasal 1 ayat (3) Undang-Undang Dasar Republik Indonesia Tahun 1945. Akan tetapi, meskipun dalam penjelasan Undang-Undang Dasar Republik Indonesia Tahun 1945 digunakan istilah rechtsstaat, namun yang dianut oleh negara Indonesia bukanlah konsep rechtsstaat maupun rule of law ${ }^{15}$. Alasannya, Konsep negara hukum sebenarnya bukanlah konsep yang lahir dari kebudayaan Indonesia melainkan dari dunia barat, sebagaimana diutarakan oleh Satjipto Rahardjo yang di kutip oleh Yance Arizona yang menyatakan bahwa:

"Negara hukum adalah konsep modern yang tidak tumbuh dari dalam masyarakat Indonesia sendiri, tetapi barang import. Proses menjadi negara hukum bukanlah merupakan bagian dari sejarah sosial-politik bangsa Indonesia di masa lalu, seperti terjadi di Eropa. Negara hukum merupakan bangunan yang dipaksakan dari luar (imposed from outside). Dengan demikian, membangun negara hukum adalah membangun perilaku bernegara hukum, membangun suatu peradaban baru" .

Satjipto Rahardjo ${ }^{16}$ dalam bukunya Negara Hukum Yang Membahagiakan Rakyatnya berpendapat bahwa negara bukan hanya merupakan bangunan hukum, politik dan sosial, melainkan juga kultural. Oleh sebab itu, kita boleh mengamati watak-watak kultural suatu negara. Disisi lain, suatu negara hukum juga "dituntut" untuk menampilkan wajah kulturalnya. Indonesia memiliki sebuah pandangan sebagai negara hukum dengan karakteristik yang khas, yaitu negara hukum Pancasila. Dalam hal ini, merujuk pada pendapat Arief Hidayat ${ }^{17}$, pada pembukaan dan pasalpasal dalam Undang-Undang Dasar Republik Indonesia Tahun 1945, konsep yang dianut negara hukum Indonesia sejak diproklamasikan kemerdekaan hingga sekarang bukanlah konsep rechtsstaat dan bukan pula konsep the rule of law. Akan tetapi membentuk suatu konsep negara hukum baru, yang bersumber pada pandangan dan falsafah hidup luhur bangsa Indonesia, yaitu negara hukum pancasila. Dimana negara hukum pancasila merupakan negara hukum yang berasaskan kepada nilai-nilai pancasila

Menurut Oemar Seno Adji yang dikutip dari Wijaya ${ }^{18}$ menyebutkan negara hukum Indonesia memiliki ciri-ciri khas Indonesia. Salah satu ciri

14 Soehino, Hukum Tata Negara Bunga RampaiHukum, Politik, Demokrasi, dan Pemerintahandi Negara Republik Indonesia, Cet-1, BPFE, Yogyakarta, 2011 hlm 55

${ }^{15}$ Qamar, N. Negara Hukum atau Negara Undang-Undang, Cet.1, Pustaka Refleksi Books. Makassar 2010, hlm 33

${ }^{16}$ Bobi Aswandi dan Kholis Roisah, Negara Hukum Dan Demokrasi Pancasila Dalam Kaitannya Dengan Hak Asasi Manusia (HAM), Jurnal Pembangunan Hukum Indonesia , Fakultas Hukum Universitas Diponegoro, Volume 1, Nomor 1, Tahun 2019 , hlm. 134, https://ejournal2.undip.ac.id/index.php/jphi/article/view/4286 diakses pada tanggal 10/09/2021. Pukul 09.21 WIB

${ }^{17}$ Ibid 
PRESUMPTION of LAW

Fakultas Hukum Universitas Majalengka

Volume 3 Nomor 2 Oktober 2021

pokok dalam negara hukum pancasila adanya jaminan terhadap kebebasan beragama sebagai pengakuan terhadap HAM. Tetapi kebebasan yang dimaksud merupakan kebebasan dalam arti positif, yang mana tidak ada tempat bagi ateisme atau propaganda anti agama di bumi Indonesia. Ciri-ciri negara hukum pancasila lainnya yaitu: hubungan yang erat antara agama dan negara, bertumpu kepada kebebasan beragama dalam arti positif, ateisme tidak dibenarkan, komunisme dilarang, asas kekeluargaan dan kerukunan. Konsep negara hukum Pancasila disamping memiliki kesamaan tetapi juga memiliki perbedaan dengan konsep negara hukum Barat baik rechtstaat, rule of law maupun socialist legality. Jika konsep negara hukum dalam pengertian rechtstaat dan rule of law berpangkal pada "dignity of man" yaitu liberalisme, kebebasan dan hak-hak individu (individualisme) serta prinsip pemisahan antara agama dan negara (sekularisme), maka latar belakang lahirnya negara hukum Pancasila didasari oleh semangat kebersamaan untuk bebas dari penjajahan dengan cita-cita terbentuknya Indonesia merdeka yang bersatu berdaulat adil dan makmur dengan pengakuan tegas adanya kekuasaan Tuhan. Karena itu prinsip Ketuhanan adalah elemen paling utama dari elemen negara hukum Pancasila. ${ }^{19}$ Begitu pula dengan Ketentuan HAM dalam UUD NRI 1945 yang menjadi basic law nya adalah norma tertinggi yang harus dipatuhi oleh negara. Karena letaknya dalam konstitusi, maka seluruh ketentuan terkait HAM harus dihormati dan dijamin pelaksanaannya oleh negara hukum Pancasila.

Hal tersebut menjadi konsekuensi yuridis dirubahnya muatan materi konstitusi terkait HAM, sehingga negara tidak bisa beralasan apapun untuk tidak mentaati ketentuan-ketentuan norma tersebut. Oleh sebab itu, Pasal 28I ayat (4) UUD 1945 menegaskan bahwa perlindungan, pemajuan, penegakan, dan pemenuhan HAM adalah tanggungjawab negara, khususnya pemerintah. Namun perlu diingat, bahwa kebabasan dan hak-hak warga negara di sini bukan tidak ada batasannya, pengaturan mengenai HAM dalam konstitusi antara hak dan kewajiban warga negara diberikan porsi yang seimbang. Kebebasan HAM terhadap manusia lainnya dibatasi oleh undang-undang. Pembatasan atas pelaksanaan HAM hanya dapat ditetapkan dengan undang-undang dengan maksud dan tujuan semata-mata untuk menjamin pengakuan dan penghormatan atas hak dan kebebasan orang lain dan untuk memenuhi tuntutan yang adil sesuai pertimbangan moral, nilainilai agama, keamanan, dan ketertiban umum dalam masyarakat demokratis. Inilah yang dimaksud dengan tidak ada hak yang dapat dilaksanakan secara mutlak, karena dibalik hak kita ada hak-hak orang lain yang wajib kita perhatikan sesuai garis yang telah ditentukan dalam falsafah Pancasila. ${ }^{20}$

${ }^{19}$ Zoelva \& Partners, Negara Hukum Dalam Perspektif Pancasila, https://zoelvapartners.id /negara-hukum-dalam-perspektif-pancasila/, diakses pada tanggal 10/09/2021. Pukul 09.21 WIB

${ }^{20}$ Abd. Muni, Hak Asasi Manusia Dalam Konstitusi Indonesia, Al Adalah Vol. 23 No. 1 2020, hlm 77, https://media.neliti.com/media/publications/340174-hak-asasi-manusia-dalamkonstitusi-indon-767db46d.pdf, diakses pada tanggal 10/09/2021. Pukul 09.21 WIB 
PRESUMPTION of LAW

Fakultas Hukum Universitas Majalengka

\section{Konsep Negara Hukum Pancasila terhadap Hak Asasi Manusia dimasa yang akan datang}

Manusia diciptakan oleh Tuhan yang Maha Esa dengan seperangkat hak yang menjamin derajatnya sebagai manusia. Hak-hak inilah yang kemudian disebut dengan hak asasi manusia, yaitu hak yang diperoleh sejak kelahirannya sebagai manusia yang merupakan karunia Sang Pencipta. Setiap manusia diciptakan kedudukannya sederajat dengan hak-hak yang sama, maka prinsip kesamaan dan kesederajatan merupakan hal utama dalam interaksi sosial. Namun kenyataan menunjukkan bahwa manusia selalu hidup dalam komunitas sosial untuk dapat menjaga derajat kemanusiaan dan mencapai tujuannya. Hal ini tidak mungkin dapat dilakukan secara individual. Akibatnya muncul struktur sosial, sehingga dibutuhkan kekuasaan untuk menjalankan organisasi sosial tersebut

Kekuasaan dalam suatu organisasi dapat diperoleh berdasarkan komitmen legitimasi religius, legitimasi ideologis eliter dan legitimasi pragmatis. Namun kekuasaan berdasarkan legitimasi di atas dengan sendirinya mengingkari kesamaan dan kesederajatan manusia, karena mengkalim kedudukannya lebih tinggi dari sekelompok manusia lainnya. Selain itu, kekuasaan yang berdasarkan ketiga legitimasi di atas akan menjadi kekuasaan yang absolut, karena asumsi dasarnya menempatkan kelompok yang memerintah sebagai pihak yang berwenang secara istimewa dan lebih tahu dalam menjalankan urusan kekuasaan negara. Kekuasaan yang didirikan berdasarkan ketiga legitimasi tersebut biasanya dipastikan akan menjadi kekuasaan yang otoriter

Konsepsi demokrasilah yang memberikan landasan dan mekanisme kekuasaan berdasarkan prinsip persamaan dan kesederajatan manusia. Dalam prinsip demokrasi, manusia ditempatkan sebagai pemilik kedaulatan rakyat. Konsepsi demokrasi dalam perkembangannya sangat terkait dengan konsepsi negara hukum. Dalam konsepsi ini, sesungguhnya hukumlah yang memerintah bukan manusia. Hukum dimaknai sebagai kesatuan hirarkis tatanan norma hukum yang berpuncak pada konstitusi. Hal ini berarti bahwa dalam sebuah negara hukum menghendaki adanya supermasi konstitusi. Supermasi konstitusi disamping merupakan konsekuensi dari konsep negara hukum, sekaligus merupakan pelaksanaan demokrasi karena konstitusi adalah wujud dari perjanjian sosial tertinggi ${ }^{21}$

Di Indonesia, negara hukum disebut juga negara hukum pancasila mengapa demikian hal itu disebabkan karena negara Indonesia adalah suatu negara yang memiliki dasar hukum pancasila dan Undang-Undang Dasar 1945. Menurut Azharry dalam Wijaya negara hukum pancasila memiliki salah satu ciri yang dominan yaitu adanya asas negara kekeluargaan. Dalam

${ }^{21}$ Ahmad Zaini, Negara Hukum Demokrasi, Dan HAM, al Qisths; Jurnal Hukum dan Politik, Vol. 11No.1Januari-Juni2020, hlm 42, http://jurnal.uinbanten.ac.id/ index.php/ alqisthas/article/view/3312/2417, diakses pada tanggal 10/09/2021. Pukul 09.21 WIB 
PRESUMPTION of LAW

Fakultas Hukum Universitas Majalengka

Volume 3 Nomor 2 Oktober 2021

asas negara kekeluargaan tersebut mengandung pengakuan terhadap hak individual, hak individual tersebut tetap mencakup hak milik atau hak asasi tetapi mengedepankan kepentingan bersama atau kepentinagn negara atau nasional daripada kepentingan pribadi atau individu. Konsep negara hukum pancasila juga memiliki prinsip dan ciri pokok yaitu negara hukum pancasila berprinsip salah satunya adanya perlindungan hak asasi manusia dengan jaminan hukum bagi tuntutan penegaknya melalui proses yang adil. Hak asasi manusia harus dihormati dan dilindungi oleh karena itu hal tersebut harus di sebarluaskan dan dipromosikan kepada seluruh masyarakat, karena hal tersebut merupakan ciri terpenting dalam suatu negara hukum yang demokratis. ${ }^{22}$

Pancasila dan UUD 1945 adalah sumber hukum di Indonesia. Pancasila ada pada pihak tertinggi segala sumber hukum dan menjadi dasar berlakunya UUD 1945. Pancasila sebagai dasar memuat pengakuan hak asasi manusia, bisa dilihat dari $:^{23}$

a. Pertama, sila "ke-Tuhanan" yang bersifat implisit kewajiban bagi warga negara kebebasan untuk mengikuti agama dan keyakinan masing-masing.

b. Kedua, sila "adil dan beradab", perintah kedua ini terwujud dalam ketentuan hukum berdirinya Indonesia dan diikuti prinsip hak asasi manusia. Nilai-nilai yang terkandung perwujudanya meliputi : menjaga melindungi jiwa atau diri lahir batin, perlindungan hidup setiap warga negara, keluarga, kehormatan dan martabatnya.

c. Ketiga, "persatuan Indonesia" yang artinya kita sebagai warga negara selalu menjunjung tinggi menjaga kedamaian untuk terciptanya persatuan Indonesia.

d. Keempat,"kerakyatan yang dipimpin oleh hikmat kebijaksanan dalam permusyawaratan perwakilan" yang artinya demokrasi.

e. Kelima, "keadilan sosial bagi seluruh rakyat Indonesia" artinya setiap orang akan mendapatkan perlakuan yang sama di depan hukum, politik, masyarakat, ekonomi dan budaya

Selain itu, tertulis dengan jelas aturan sebanyak 17 pasal dengan 38 sub bab hak yang bermacam-macam. HAM yang ada pada Pancasila dan UUD 1945 kemudian dituangkan dalam undang-undang. Konsep negara hukum khas Indonesia bersumber dari cita hukum dan keyakinan hukum serta praktiknya dalam ketatanegaraan Indonesia. Negara hukum Pancasila, memandang Ketuhanan Yang Maha Esa sebagai causa prima, tidak akan memberikan toleransi jaminan konstitusional kebebasan anti agama hidup di tengah-tengah tata hukum Indonesia. Negara hukum Indonesia mempunyai ciri-ciri tersendiri yang menunjukkan aspek-aspek khusus dari hak asasi : antara lain tidak memisahkan antara agama dengan negara, adanya pengakuan hak-hak asasi manusia seperti dikenal di Barat, adanya

${ }^{22}$ Rizkyana Tri Nandini , Anita Trisiana , Dina Yeti Utami, Relevansi Ham Dalam Perspektif Hukum Di Indonesia, Bhineka Tunggal Ika: Kajian Teori dan Praktik Pendidikan PKN Volume 08, No. 01, Mei 2021, hlm 44 https://ejournal. unsri. ac.id/ index. php/jbti/ article/ view/ 13362/pdf, diakses pada tanggal 10/09/2021. Pukul 09.21 WIB

${ }^{23}$ Ibid 
PRESUMPTION of LAW Fakultas Hukum Universitas Majalengka

pengakuan atas hak-hak sosial ekonomi rakyat yang harus dijamin dan menjadi tanggung jawab negara- yang isinya berbeda jalannya dengan konsep rule of law ataupun socialist legality. Di samping itu negara hukum Pancasila memiliki asas khas Indonesia yaitu asas musyawarah dan gotong royong yang dalam praktik sangat diutamakan, khususnya dalam bidang politik kenegaraan.

Perlindungan Hak Asasi Manusia sudah menjadi asas pokok dalam kehidupan bernegara di Indonesia. Hal ini terbukti dari pernyataan UndangUndang Dasar Republik Indonesia 1945 dalam pembukaannya di Alinea pertama yang menyatakan bahwa " kemerdekaan ialah hak segala bangsa, maka penjajahan harus dihapuskan karena tidak sesuai dengan peri kemanusiaan". Hal ini berarti adanya "freedom to be free", yaitu kebebasan untuk merdeka, dan pengakuan atas perikemanusiaan telah menjelaskan bahwa Bangsa Indonesia mengakui akan adanya hak asasi manusia.. Prinsip-prinsip HAM secara keseluruhannya sudah tercakup didalam Undang- Undang Dasar Republik Indonesia 1945. Prinsip universalitas yang merupakan bentuk menyeluruh, artinya setiap orang/tiada seorangpun tanpa memandang ras, agama, bahasa, kedudukan maupun status lainnya,di mana setiap orang memiliki hak yang sama dimata hukum, namun prinsip universalitas tidak keseluruhannya terkandung dalam Undang-Undang Dasar Republik Indonesia 1945, hal ini dibuktikan dari pernyataan di dalam pembukaannya yaitu: "melindungi segenap bangsa Indonesia dan seluruh tumpah darah Indonesia "Hal ini berarti Negara hanya bertanggung jawab kepada hak dari seluruh warga Indonesia saja. Begitu juga dengan beberapa pasal yang mengistilahkan "setiap warga Negara/tiap-tiap warga Negara”, seperti pada Pasal 27 ayat (1), (2), Pasal 30 ayat (1),Pasal 31 ayat (1) Padahal yang dimaksudkan sebagai prinsip universal adalah ketentuan hak yang berlaku bagi semua orang, bukan terbatas pada wilayah tertentu. ${ }^{24}$

Pancasila sebagai filsafat bangsa dan ideologi negara dihubungkan dengan fungsinya sebagai dasar negara, yang merupakan landasan idiil bangsa Indonesia dan negara Republik Indonesia dapat disebut pula sebagai Ideologi Nasional atau lebih tepat lagi ideologi negara. Artinya Pancasila merupakan satu ideologi yang dianut oleh negara atau pemerintah dan rakyat Indonesia secara keseluruhan, bukan milik atau dapat dimonopoli oleh seseorang, ataupun sesuatu golongan masyarakat tertentu. Sebagai dasar filsafat atau dasar kerohanian negara, yang merupakan cita-cita bangsa, Pancasila harus dilaksanakan atau diamalkan. Bangsa Indonesia, dalam perjalanan sejarahnya mengalami kesengsaraan dan penderitaan yangg disebabkan oleh penjajahan. Oleh sebab itu Pembukaan UndangUndang Dasar 1945, mengamatkan bahwa kemerdekaan adalah hak segala bangsa dan penjajahan diatas dunia harus dihapuskan karena tidak sesuai dengan perikemanusiaan dan perikeadilan. Bangsa Indonesia bertekad mengikuti ketertiban dunia berdasarkan kemerdekaan, perdamaian abadi dan

${ }^{24}$ Serlika Aprita, dan Hj. Yonani Hasyim, Hukum dan Hak Asasi Manusia, Mitra Wacana Media, , Jakarta, 2020. hlm 69 
PRESUMPTION of LAW

Fakultas Hukum Universitas Majalengka

Volume 3 Nomor 2 Oktober 2021

keadilan sosial yang pada hakikatnya merupakan kewajiban setiap bangsa, sehingga bangsa Indonesia berpandangan bahwa hak asasi manusia tidak terpisahkan dengan kewajibannya ${ }^{25}$. Di satu sisi harus diakui bahwa saat ini sudah banyak kemajuan di bidang HAM yang diraih oleh Indonesia. Namun di sisi lain, masih banyak upaya yang harus dilakukan untuk memperbaiki situasi HAM di Indonesia di masa yang akan datang. Kemajuan yang telah dicapai Indonesia misalnya pada rezim Orde Reformasi Indonesia mengeluarkan Undang-Undang Nomor 39 Tahun 1999 Tentang Hak Asasi Manusia dan Undang-Undang Nomor 26 Tahun 2000 Tentang Pengadilan Hak Asasi Manusia. Pada tahun 2000 juga dilakukan Amandemen II UUD Negara Republik Indonesia Tahun 1945 yang mencantumkan Bab XIA tentang Hak Asasi Manusia khususnya ketentuan Pasal 28A-28J 9 dan Pasal 28, 29, 30, 31, 33, 34. Substansi dari Amandemen II UUD NRI Tahun 1945 ini menjadi landasan yuridis dalam upaya perlindungan dan pengakuan HAM baik di bidang hak sipil dan politik serta hak ekonomi, sosial dan budaya.

Meluasnya jaminan hak-hak asasi manusia melalui pasal-pasal di dalam UUD 1945 hasil dari Amandemen II tersebut merupakan kemajuan dalam membangun pondasi hukum bernegara untuk memperkuat kontrak penguasa-rakyat dengan semangat konstitusionalisme Indonesia. ${ }^{26} \mathrm{Namun}$ sampai sekarang situasi perlindungan HAM masih lemah terlihat dengan banyaknya pelanggaran HAM di Indonesia baik dibidang hak sipil dan politik maupun hak ekonomi, sosial dan budaya. Di bidang hak sipil misalnya perlindungan hak kebebasan beragama dan beribadah masih banyak hambatan. Dalam catatan ELSAM mencatat setidaknya terdapat 63 kasus pelanggaran hak atas kebebasan beragama atau berkeyakinan yang dilakukan dalam berbagai bentuk antara lain kebijakan diskriminatif, pembakaran rumah ibadah, pembakaran rumah jemaat, penyerangan, tindakan pembiaran oleh aparat, dll. Dari catatan tersebut, pelanggaran terhadap kebebasan beragama atau berkeyakinan, justru paling sering dilakukan oleh pemerintah daerah, sebagai institusi yang seharusnya memberikan perlindungan bagi semua warganya, tanpa kecuali. Hal ini tentunya menimbulkan tanda tanya, Mengapa disaat upaya perlindungan hukum Hak Asasi Manusia di Indonesia mengalami kemajuan, isu mengenai pelanggaran HAM kembali mencuat dan hangat diperbincangkan. Dengan

${ }^{25}$ Luh Suryatni, Pancasila Sebagai Ideologi Negara Dan Hak Asasi Manusia Dalam Menjaga Keutuhan Negara Kesatuan Republik Indonesia, Jurnal Ilmiah Hukum Dirgantara Fakultas Hukum Universitas Suryadarma Volume 5 No.1, September 2014, hlm 46, http:// download.garuda.ristekdikti.go.id/article.php? article=972020\&val=14963\&title= PANCASILA \%20SEBAGAI\%20IDEOLOGI\%20NEGARA\%20DAN\%20HAK\% 20 ASASI \%20 MANUSIA \%20DALAM\%20MENJAGA\%20KEUTUHAN\%20NEGARA\%20KESATUAN\% 20REPUBLIK\%20INDONESIA. diakses pada tanggal 10/09/2021. Pukul 09.21 WIB

${ }^{26}$ R. Herlambang Perdana Wiratrama, Hak-Hak Konstitusional Warga NegaraSetelah Amandemen UUD 1945: Konsep, Pengaturan dan Dinamika Implementasi, Jurnal Hukum Panta Rei, Vol. 1, No. 1 Desember 2007, https://www.academia.edu/28151261/Hak-Hak_ Konstitu-sional_Warga_Negara_Setelah_Amandemen_UUD_1945_Konsep_Pengaturan_dan_ Dinami-ka_Implementasi. . diakses pada tanggal 10/09/2021. Pukul 09.21 WIB 
demikian adalah sebuah keniscayaan, pemerintah harus terus meningkatkan pemahaman masyarakat tentang pentingnya perlindungan HAM juga menjadi salah aspek penting dalam mendorong upaya pemerintah dalam melaksanakan kewajiban tersebut. Oleh karena itu dalam memahami HAM perlu kiranya mengetahui konsep dasar, prinsip-prinsip dasar serta regulasi HAM baik di tingkat Internasional maupun nasional sehingga masyarakat mampu mengawal sekaligus mendesakan pemenuhan HAM oleh Negara secara cepat dan tepat, sehingga praktek-praktek pelanggaran HAM atau pengabaian HAM serta pembiaran terhadap praktek-praktek pelanggaran HAM di Indonesia semakin berkurang. Hasilnya timbul rasa aman bagi setiap individu yang tinggal di seluruh wilayah Republik Indonesia. ${ }^{27}$

\section{F. Kesimpulan}

1. Salah satu ciri pokok dalam Negara Hukum Pancasila adanya jaminan terhadap kebebasan beragama sebagai pengakuan terhadap HAM. Dalam konteks negara hukum pancasila, HAM telah termuat didalam pancasila itu sendiri. Dalam sila pertama misalnya Ketuhanan Yang Maha Esa. Yang pada prinsipnya telah menegaskan adanya kebebasan bagi setiap warga negara untuk memeluk agama dan kepercayaannya masing-masing, namun kebebasan yang dimaksud merupakan kebebasan dalam arti positif, yang mana tidak ada tempat bagi ateisme atau propaganda anti agama di bumi Indonesia

2. Konsep negara hukum Pancasila disamping memiliki kesamaan tetapi juga memiliki perbedaan dengan konsep negara hukum Barat baik rechtstaat, rule of law maupun socialist legality. Meluasnya jaminan hak-hak asasi manusia melalui pasal-pasal di dalam UUD 1945 hasil dari Amandemen II tersebut merupakan kemajuan dalam membangun pondasi hukum bernegara dan harus diakui bahwa saat ini sudah banyak kemajuan di bidang HAM yang diraih oleh negara hukum Pancasila. Namun di sisi lain, masih banyak upaya yang harus dilakukan untuk memperbaiki situasi HAM di Indonesia di masa yang akan datang sehingga praktek-praktek pelanggaran HAM atau pengabaian HAM serta pembiaran terhadap praktek-praktek pelanggaran HAM di Indonesia semakin berkurang..

\section{G. Saran}

1. Bagi masyarakat diharapkan bisa menerapkan sikap saling menghormati, saling menghargai, saling toleransi, saling gotong royong, dan saling bertenggang rasa., agar tercipta kehidupan beragama yang baik dan rukun

2. Kepada pemerintah, supaya keadilan dan kepastian hukum bisa dirasakan oleh setiap warga Negara, diharapkan untuk menindak tegas para pelaku pelanggaran Hak Asasi Manusia tanpa membedakan agama, ras, suku

27 Cekli Setya Pratiwi, Hak Asasi Manusia: Konsep Dasar, Prinsip-prinsip dan Instrumen HAM Internasional dan Pengaturannya Di Indonesia, https://papers.ssrn.com/ sol3/papers.cfm? abstract_id=3304096 diakses pada tanggal 10/09/2021. Pukul 09.21 WIB 
PRESUMPTION of LAW Fakultas Hukum Universitas Majalengka

Volume 3 Nomor 2 Oktober 2021

bangsa, warna kulit, ideology, miskin atau kaya, pejabat atau rakyat biasa, maupun sipil atau militer 


\section{DAFTAR PUSTAKA}

\section{A. Buku :}

Bambang Waluyo, Penelitian Hukum dan Praktek, Cetakan Ketiga, Sinar Grafika, Jakarta, 2002.

Burhan Ashshofa, Metode Penelitian Hukum, PT . Rhineka Cipta, Jakarta, 1996.

Munir Fuady, 2009, Teori Negara Hukum Modern (Rechtstaat), Refika Aditama, Bandung.

Nany Suryawati, Hak Asasi Politik Perempuan, Ideas Publishing, Gorontalo, 2020.

Peter Mahmud Marzuki, Penelitian Hukum, EdisiRevisi, Kencana, Jakarta, 2013.

Qamar, N. Negara Hukum atau Negara Undang-Undang, Cet.1, Pustaka Refleksi Books. Makassar 2010.

Serlika Aprita, dan Hj. Yonani Hasyim, Hukum dan Hak Asasi Manusia, Mitra Wacana Media, , Jakarta, 2020.

Soehino, Hukum Tata Negara Bunga RampaiHukum, Politik, Demokrasi, dan Pemerintahandi Negara Republik Indonesia, Cet-1, BPFE, Yogyakarta, 2011.

\section{B. Peraturan Perundang-undangan}

Undang-Undang Dasar Negara Republik Indonesia Tahun 1945

Undang-Undang Nomor 39 Tahun 1999 Tentang Hak Asasi Manusia

Undang-Undang Nomor 26 Tahun 2000 Tentang Pengadilan Hak Asasi Manusia

\section{Sumber Lain:}

Abd. Muni, Hak Asasi Manusia Dalam Konstitusi Indonesia, Al Adalah Vol. 23 No. 1 2020, https://media.neliti.com/media/publications/340174-hakasasi-manusia-dalam-konstitusi-indon-767db46d.pdf, diakses pada tanggal 10/09/2021. Pukul 09.21 WIB

Ahmad Zaini, Negara Hukum Demokrasi, Dan HAM, al Qisths; Jurnal Hukum dan Politik, Vol. 11No.1Januari-Juni2020, http://jurnal.uinbanten.ac.id/ index.php/ alqisthas/article/view/3312/2417, diakses pada tanggal 10/09/2021. Pukul 09.21 WIB 
PRESUMPTION Of LAW

Fakultas Hukum Universitas Majalengka

Volume 3 Nomor 2 Oktober 2021

Ayomi Amindoni, Covid-19 Memperburuk Situasi Ham Di Indonesia Pada 2020, Dengan Korban Lebih 150 Orang, 'UU ITE Masih Menjadi Momok', https:// www.bbc. com/indonesia/indonesia-56664120, diakses diakses pada tanggal 09/09/2021. Pukul 21.05 wib

Bobi Aswandi dan Kholis Roisah, Negara Hukum Dan Demokrasi Pancasila Dalam Kaitannya Dengan Hak Asasi Manusia (HAM), Jurnal Pembangunan Hukum Indonesia, Fakultas Hukum Universitas Diponegoro, Volume 1, Nomor 1, Tahun 2019, https:// ejournal2 .undip. ac.id/index.php/jphi/article/view/4286 diakses pada tanggal 10/09/2021. Pukul 09.21 WIB

Cekli Setya Pratiwi, HAK ASASI MANUSIA: Konsep Dasar, Prinsip-prinsip dan Instrumen HAM Internasional dan Pengaturannya Di Indonesia, https://papers.ssrn.com/ sol3/papers.cfm? abstract_id=3304096 diakses pada tanggal 10/09/2021. Pukul 09.21 WIB

I Ketut Cahyadi Putra, Relevansi Konsep Negara Hukum Pancasila Dengan Welfare State Dalam Implementasinya Dengan Pelayanan Publik Di Indonesia, Jurnal, Magister Hukum Udayana, Vol. 6, No. 1, 2017, https://ojs.unud.ac.id/index.php/jmhu/article/view/30607, diakses pada tanggal 09/09/2021. Pukul 21.05 WIB

Lilis Eka Lestari, Penegakan Dan Perlindungan Hak Asasi Manusia Di Indonesia Dalam Konteks Implementasi Sila Kemanusiaan Yang Adil Dan Beradab, Jurnal Komunilasi Hukum, Vol. 5 No. 2, Agustus 2019, https://ejournal.undiksha.ac.id/ index.php/ jkh/article/view/16497, diakses pada tanggal 10/09/2021. Pukul 09.21 WIB

Luh Suryatni, Pancasila Sebagai Ideologi Negara Dan Hak Asasi Manusia Dalam Menjaga Keutuhan Negara Kesatuan Republik Indonesia, Jurnal Ilmiah Hukum Dirgantara - Fakultas Hukum Universitas Suryadarma Volume 5 No.1, September 2014, http:// download. garuda. ristekdikti. go.id/article.php? article $=972020 \&$ val $=14963 \&$ title $=$ PANCA-SILA $\%$ 20SEBAGAI\% 20IDEOLOGI\% 20NEGARA \%20DAN\%20HAK\% 20 ASASI $\% 20$ MANUSIA\%20 DALAM \%20MENJAGA \%20 KEUTUHAN\%20NEGARA\%20KESATUAN\%20REPUBLIK\%20IND ONESIA. diakses pada tanggal 10/09/2021. Pukul 09.21 WIB

Otong Syuhada, Karakteristik Negara Hukum Pancasila Yang Membahagiakan Rakyatnya, Journal Presumption of Law, Volume 3 Nomor 1 April 2021 $\mathrm{hlm} 3 \mathrm{https} / / /$ ejournal. unma.ac.id/ index.php/jpl/article/view/979 diakses pada tanggal 09/09/2021. Pukul 21.05 WIB

R. Herlambang Perdana Wiratrama, Hak-Hak Konstitusional Warga NegaraSetelah Amandemen UUD 1945: Konsep, Pengaturan dan Dinamika Implementasi, Jurnal Hukum Panta Rei, Vol. 1, No. 1 Desember 2007, https://www.academia.edu/28151261/Hak-Hak_ 
Konstitusional_ Warga_Negara_Setelah_Amandemen_ UUD_1945_ Konsep_Pengaturan_ dan_ Dinamika_Implementasi. diakses pada tanggal 10/09/2021. Pukul 09.21 WIB

Rizkyana Tri Nandini , Anita Trisiana, Dina Yeti Utami, Relevansi Ham Dalam Perspektif Hukum Di Indonesia, Bhineka Tunggal Ika: Kajian Teori dan Praktik Pendidikan PKN Volume 08, No. 01, Mei 2021, https://ejournal. unsri. ac.id/ index. php/jbti/ article/ view/ 13362/pdf, diakses pada tanggal 10/09/2021. Pukul 09.21 WIB

Rukmana Amanwinata, "Pengaturan dan Batas Implementasi Kemerdekaan Berserikat dan Berkumpul dalam Pasal 28 UUD 1945”, Disertasi, Program Pascasarjana Universitas Padjadjaran, Bandung, 1996.

Zoelva \& Partners, Negara Hukum Dalam Perspektif Pancasila, https:// zoelvapartners.id /negara-hukum-dalam-perspektif-pancasila/, diakses pada tanggal 10/09/2021. Pukul 09.21 WIB 